\title{
David Patrick Chapman MCSP, SRP
}

We report with regret the death of David Patrick Chapman, former Honorary Secretary of BASM, on 23 September 1992.

David was born in Margate in 1928, educated at Chatham House School, Ramsgate, and began physiotherapy training after army service in the Royal Tank Regiment. His active sports included sprinting and rugby to county level and later embraced hunting wild boar, shooting and fishing. He played proudly for Wasps RFC till moving to Sussex in 1959 and joining Eastbourne and then being active also in the formation of his local club at Heathfield. He revelled in sport's companionship, toured the Caribbean with the Golden Oldies in his late 40 s and it took a broken tibia to persuade him to hang up the boots at 50 ! We have happy memories of David refereeing a BASM Loughborough course mixed rugger match, calling time-outs related more to his nicotine levels than the clock!

Meanwhile, he and his wife Marjorie, a nurse, set up a unique local residential and outpatient clinic for physiotherapy and rehabilitation with special emphasis on sports injuries. He gave time and treatments unstintingly and his motto of 'have boots will travel' took him far and wide with county and other teams.

David was active in the development of the Association of Chartered Physiotherapists in Sports Medicine (ACSPM) and felt greatly honoured to have served a spell as its President. It was his enthusiasm, energy and integrity which helped to forge close links between ACPSM and BASM and led to his election to BASM committee.

David was a tower of strength to BASM for many years, usually as an utterly reliable back-up in the organization of our meetings and courses. His 'savvy' and ability to fix any crisis became indispensible. Many Loughborough course veterans will treasure their own memories of David's personality!

He became Assistant Secretary and then the first non-doctor BASM Honorary Secretary from 1983 to 1986 when, alas, a stroke slowed him down. His commitment and totally unselfish loyalty gave BASM great support at a time of difficult changes.

Outside sport and medicine, he was a founder member of the Heathfield Round Table and was active as a mason. No farmer himself, he was associated with the Heathfield Agricultural Show. All he did, he did with heart and soul. The huge turn-out at his memorial service was sure testimony to his immense popularity and we all silently applauded the preacher's lament 'We have lost a character' as we looked on his brightly polished rugger boots and shooting hat atop the coffin and tried to heed his last wish that the ceremony should not be mournful, but a celebration of his life.

Our deepest condolences go to Marjorie, his sons, daughter and grandchildren.

M.C., P.N.S. 